\title{
Governance after Financial Crisis: South American Perspectives on the Reformulation of Regionalism
}

\author{
NICOLA PHILLIPS
}

With the recent financial crises in Asia, Russia and Brazil, the resurgence of debate on the 'management' of globalisation has thrown into doubt a number of the 'certainties' which policy makers constructed to deal with the 'uncertainties' of a post-Cold War, globalising world order. These 'certainties' centred around the dominance of the 'Washington Consensus', the euphoria of 'globalisation' and the heralding of an inexorable march towards a truly 'global' economy, and the notion of the 'information age' and the 'digital revolution' which eliminated cumbersome national boundaries and 'shrunk' the world into something approximating a 'global village'. Academic and policy debate, bored with the monotony (and inaccuracy) of this 'hyper-globalisation' discourse and, perhaps, with contesting yet again the alleged disappearance of the states, has turned of late towards a 'restructuring' agenda: restructuring of, for example, the financial architecture, the regulatory role of the national state, global markets, multilateral institutions and, crucially, the conceptual foundations of our understanding of international political economy (IPE).

Neoclassical economists' stubborn refusal to treat social and political variables as anything other than exogenous to the mainstream of market activity has been challenged by a growing intellectual preoccupation among international political economists (and other social scientists) with the normative connotations of the particular configuration of economic and political power implied by the term 'globalisation'.' This emerging normative agenda found particular expression in responses to the 'crises of market fundamentalism' occasioned by the financial turbulence of 1997-9. The 'no-alternative' rhetoric of globalisation appears to have given way to a more nuanced understanding of processes of global change and, moreover, of the sociopolitical consequences of the 'commodification' of economic and social relations. Most importantly, the financial crises propelled a renewed emphasis on the agency of state and non-state actors in directing, managing, perhaps mitigating the impact of the specific types of global economic activity that dominated the 1990s. In short, there appears to be underway a

Nicola Phillips, Department of Politics and International Studies, University of Warwick, Coventry CV4 7AL, UK. 
rethinking of development models and policy principles, as well as the institutional configurations associated with them.

So where and how does regionalism fit into this picture? This article focuses on the ways in which financial crisis has altered conceptions and forms of regionalism in the global political economy, and thus compels a change in our theoretical understanding s not only of regionalist dynamics but also of 'governance' in the broader sense. ${ }^{2}$ To this end, my aim is to look through a South American lens at the central issues involved in the reformulation of regionalism. I propose to do this by setting out a series of three interconnected responses to the question of where regionalism fits into a 'post-globalisation', 'post-Washington Consensus ${ }^{4}$ reconsideration of key structures, development models and policy issues. These are considered in turn in successive sections of the article.

The first part of the argument is that the financial crises, by propelling an important 'globalisation backlash', ${ }^{5}$ contributed to significant shifts in the articulated interests of states and the policy agendas through which these interests are pursued. Given, as we will see, that regionalis $m$ is inherently a project driven by states and a significant means by which some measure of policy latitude threatened by globalisation might be salvaged, there is a persuasive argument to be made that the domestic impact of recent global trends will necessarily involve a redefinition of the bases of regionalism in various parts of the world. In addition, if the central foundations on which contemporary regional arrangements are constructed are challenged, modified or torn down, then it seems reasonable to expect, supported by recent evidence, that the nature of the resulting regional projects will undergo a consequent and related process of change.

The second idea focuses on the articulation (or not) of regional responses to financial volatility. As yet, the literature on financial crisis has tended to focus on the implications of turmoil for 'regions'-especially with reference to such phenomena as 'contagion'-with little sustained attention to the impact on regional projects. There is a generalised assumption, though, that recent instability has generated a 'relegitimation of the containment effects of neo-regional arrangements'. ${ }^{6}$ This is an attractive proposition given the somewhat pitiful prospects for individual countries to respond in meaningful fashion to financial crisis in view of its scale in various regions. The idea of imposing capital controls, for example, intuitively seems more viable in the context of a concerted effort among various players, at least some of whom might hold sufficient 'structural power' to have some sort of significant impact on outcomes. The wisdom holds, furthermore, that, if regionalism is assumed to capitalise on commonalities of interests among member states, the notion of collective responses to global instability similarly will be informed by a convergence of 'interests' reflective of common circumstances.

Nevertheless, evidence from various regions does not bear out unequivocally the contention that collective responses to volatility in the global capitalist economy are desired or indeed viable. Contrary to the apparent consensus that the crises will act to strengthen regionalism, developments in South America and elsewhere ${ }^{7}$ appear to suggest that in the short term possibilities for collective action are weakened and regional projects are as likely to fragment as to 
coalesce. However, from a longer-run perspective, it seems probable that the consequences of this process of change will favour the articulation of stronger regional identification, which may well lead to an important redefinition of the nature and patterns of contemporary regionalism. Of late, perhaps since the Mexican crisis, the neoliberal 'credibility' effect of regionalism has become less relevant than its importance as a means of shoring up national economies against the crisis-generating nature of global capitalism. For many, therefore, the most pertinent function of regional integration will be increasingly its defensive potential against the vagaries of global capitalism, on the one hand, as much as its importance as a mechanism for collective action, on the other. In the context of current shifts in approaches to globalisation, the question is how some sort of reconstituted regionalism will relate to broader 'global' trends.

This leads into the third idea about how regionalism is implicated in recent global instability. The final part of the article offers some preliminary thoughts on the implications of these trends for current imaginings of the future of global governance. A 'regionalisation' of the 'post-globalisation' world order potentially undermines the central principles of global liberalisation which depend crucially on the now threadbare idea of 'convergence'. The progressive articulation of regional difference, as well as the 'regionalisation' of policy agendas, generates important questions about the future trajectory of 'governance'. Moreover, to conceive of world order in regionalist terms of a future 'triadic' structure of global governance is problematic, principally in its neglect of the regional trends identified in the bulk of this article. The resulting dynamic in the global political economy is thus more likely to be one of tension between the forces of regionalism and globalism than one of mutual reinforcement in which global and regionalist governance serve the same global ends.

\section{States, interests and regional alliances}

Along with the longstanding debate in mainstream globalisation theory over the 'retreat' of the state ${ }^{8} v s$. its rehabilitation in new areas of competence and authority, ${ }^{9}$ mainstream theories of regionalism remain somewhat ambivalent about the significance of national states in a range of regional arrangements. The recent confluence of currents in comparative politics, which call for a more rigorous understanding of the complexity of state-society interactions in conditions of 'structured privilege', and currents in IPE, which emphasise the 'transnationalisation' of political activity and the diffusion of power away from its exclusive concentration in the structures of national states, have provided useful avenues for theorising the politics of regionalism. ${ }^{10}$ An important strand of the research agenda on regionalism in recent years has been the concern with regionalist 'governance' which, for good reason, takes as its principal laboratory the European Union. The concern with supranationalis $m$ and the attractive notion of "multilevel governance"11 have generated a theoretical movement away from traditional Westphalian understandings of states and sovereignty. Under condition s of globalisation, states have lost or surrendered a significant degree of policy-making latitude as a result of the compression of time and space, the primacy of global (especially financial) markets and the 
increasing salience of transnational power structures and non-state forms of authority. As is now well understood, however, these arguments are not incompatible with more 'national' perspectives on the state which emphasise its continuing monopoly over political legitimacy and its continuing centrality in policy management and the arbitration of social conflict.

Ideas about the 'pooling' of sovereignty at the regional level often fall into the same trap as arguments that equate globalisation with the disappearance of states. From a 'global' perspective, regionalis m constitutes a transnationalisation of economic and political activity, which implies the transcendence of state boundaries in the interests of ensuring cooperation and reducing the potential for conflict, of whatever description, between geographically (and perhaps culturally) proximate partners. From a 'bottom-up' perspective, the formation of a regional bloc is concerned with various dimensions of state-building. The rationale for regionalism is invariably that there are common goals which can best be pursued in concert with other states or actors. Rather than implying a loss of 'statehood', regional arrangements allow not only for the elaboration of appropriate responses to the pressures of global liberalisation, ${ }^{12}$ but also for the maintenance of some degree of 'discretion' in the management of domestic policy issues and the salvaging of effectiveness in specific policy areas. The 'regionalisation' of social or industrial policy, for example, or the regional negotiation of policy in sensitive areas such as agriculture or automobile industrie s permit governments to attempt to reconcile in some constructive way priorities peculiar to the 'national' (and perhaps 'regional') setting with the internationalisation of economic activity under conditions of market globalisation.

Whether or not we choose to focus on the multilevel governance structures of the EU, then, we are drawn to Gamble and Payne's definition of regionalis $m$ as a 'state-led or states-led project' which remains crucially 'statist' in its various manifestations, as distinct from the social process implied by the term 'globalisation'. ${ }^{13}$ Thus, the 'globalisation and the state' debate differs from questions about the national state in regionalism, the latter departing from the notion that regionalism is a specific policy project propelled and directed by states, notwithstanding complex relationships with non-state agency and the emergence of increasingly complex notions and structures of governance. The momentum of regionalism relies on 'palpable' manifestations of state action (treaties, trade agreements, formal and informal institutionalisation, intergovernmental decisions) which are in many respects lacking from contemporary manifestations of 'globalisation'. Regionalism must necessarily be understood as a constructed product of human agency. ${ }^{14}$ In this sense, the regional dimensions of structural change have long been something of an inconvenience for the less reflexive of 'globalisers' who have used the hegemonic discourse of globalisation to dispense with any meaningful notion of a national state.

South American regionalism is notable for the extent to which states occupy, almost exclusively, the epicentre of the regionalist project. The transfer of political authority from national governmental structures to specialist policy communities and the supranational structures of the EU find few parallels in the Mercosur. ${ }^{15}$ In the same way as South American politics remain inconveniently 
statist for those that wish to proclaim a decisive shift in the location of political power towards non-state sites of authority, regionalism bears the imprint of this particular centralised type of state-society interaction. The Mercosur is not entirely without institutions, but its institutional structure is wholly intergovernmental, rather than supranational. The two intergovernmental bodies created by the Treaty of Asunción - the Common Market Council (CMC) and the Common Market Group (GMC) — are composed (in the case of the former) of the Foreign and (usually) Economy Ministers of each member country and (in the case of the latter) of representatives of the Foreign Ministries, Economy Ministries and Central Banks. Virtually without exception presidential meetings and negotiations dominated the major summits between Mercosur countries in the 1990s. Apart from the small bureaucracy of so-called 'Mercocrats' which makes up the Administrative Secretariat, the integration process in Mercosur is handled by groups of officials in the relevant ministries in each of the member countries. Therefore, the technocratic teams remain located at national level, rather than at supranational level as in the EU. They remain politically accountable to their respective governments and responsive to other state agencies (especially those concerned with economic policy), provincial governments and national business interests. ${ }^{16}$

Business interests remain underrepresented in the Mercosur, notwithstanding the formation of the Economic and Social Consultative Forum in 1994 and important advances in cooperation between national business communities in the late 1990s. The preference has remained for informal bargaining channels and lobbying activities as opposed to further regional institutionalisatio $n$ that would give more formal expression to business interests. As a result, business interests are articulated in regional negotiation s through the structures of the states. That trade union input which exists is similarly mediated by national governmental structures. Other actors, such as political parties, small firms and social movements, remain to date of relatively marginal importance in the formal structures and operations of the Mercosur. As such, the South American case currently conforms far more closely with the arguments of the 'intergovernmentalist' camp in the literature on EU regionalis $\mathrm{m}^{17}$ than the neofunctionalist emphasis on supranationalis $\mathrm{m}$ or the 'decisional reallocation' of multilevel governance approaches.

So where does all this lead us? First, it affirms that regionalist projects (and perhaps especially the South American) remain dominated by state actors and, by extension, the interests of states at a given historical moment. (The extent and ways in which the states can be seen as an aggregation of interests, and the dynamics that we observe in the construction of what eventually become the 'interests' of states, require empirical elaboration on the basis of individual cases). Second, it concentrates attention on the particular historical moment in which global, regional and domestic orders are currently situated. The financial crises of 1997-9 propelled a questioning of the dominant global orthodoxy in a variety of ways. One of these concerns policy choice, in which the most important agents remain national governments and state actors. The process of rethinking central tenets of development models necessarily involves reconfigurations of political and economic power, which consequently propel 
reassessments of participation in the global political economy and the construction of regional orders. It is significant that national states are central to both of these mutually constitutive processes: the rethinking of policy ideas privileges a rethinking of the parameters of state action, state authority and state responsibility, which feeds into a state(s)-led project of change at the regional level.

Given that the latest 'wave' of regionalism was constructed to complement and reinforce neoliberal reform processes (notably in Latin America), it is reasonable to expect that the questioning of the fundamentals of neoliberalism will be reflected in the nature of regionalist projects. While the extent of this questioning should not be exaggerated, it is evident that the zealous commitment to neoliberal restructuring in the early 1990s had been superseded by the end of the decade by an awareness among policy elites and societies in the affected countries that adherence to such a strict set of policy measures had not generated a solid basis for growth and development, nor for the continued dynamism of global capitalism. The disillusion occasioned by burgeoning social dislocations - consequent upon shifts in employment structures and tax burdens-combined with a marked resentment of both private financial agents and IMF-Treasury elites in the aftermath of financial crisis to produce a generalised backlash against globalisation, of which trends in South America form part. ${ }^{18}$

The result was the emergence of a genuine (though to date less than concrete) debate in policy and academic circles on potential means of 'governing' globalisation and of making good the notion of the 'social market'. At the 1999 and 2000 meetings of the World Economic Forum and G7 summits, much was made of the apparent trade-off between international competitivenes $s$ and the social and political priorities of democratic systems. ${ }^{19}$ Privatisation and deregulation in welfare provision, especially, were recognised to have contributed to rising levels of domestic inequalities, and the 'logic' of international restructuring to have fed into an increasingly painful differentiation between rich and poor countries. Social injustice came during this time to be associated with the absence of effective economic regulation, or at the very least with the process of deregulation which most countries were engaged in engineering for much of the 1990s. By the end of the decade, there were thus increasing but still muted calls, some emanating from the discipline of economics, to recognise the negative correlation between social stability and 'purist' forms of neoliberal globalisation. ${ }^{20}$ As a result, the objectives of market economics were seen to stand in need of re-evaluation as much as the functioning of the market economy itself.

'Reform fatigue'"21 became entrenched among Latin American electorates over the course of the 1990s. The politics of the spate of presidential elections at the end of the decade demonstrated that, while public opinion stopped short of condemning the fundamentals of the economic model, support had become notably contingent on governments' commitment to mediating the socially deleterious effects of global liberalisation. What was needed, Latin Americans argued, was a novel approach to economic and social governance which displayed flexibility and imagination-'intelligent solutions', in short, 'even if they don't feature in Economics textbooks'. ${ }^{22}$ Current evidence accordingly 
suggests that the future trajectory of policy in South America will reflect a trend away from 'automatic pilot' market strategies towards more active policies of the types enshrined in the Asian 'developmental state' model and now advocated in Latin America by a growing number of governmental, societal and media voices.

This condemnation of the 'stateless market' points to a (re-)recognition (in policy intellectual circles) of the institutional and social embeddedness of markets as well as the ways in which the functioning of domestic and global markets depends on the generation of political consent. ${ }^{23}$ The presence of highly mobile international capital and processes of commercial and financial liberalisation proved over the 1990s to be socially unworkable in emerging economies which are not possessed of the sorts of domestic compensatory mechanisms found in the industrialised countries. ${ }^{24}$ In some cases, notably Venezuela, traditional antagonisms to the Anglo-American neoliberal agenda and resistance to 'globalisation' became increasingly pronounced. There and elsewhere, this scepticism prompted echoes in some quarters of pre-globalisation, pre-reform arguments that developing countries are neither ready for, nor suited to, globalisation. $^{25}$

The Southern Cone countries did not at this time exhibit such strong insertion into a generalised 'globalisation backlash', but certainly exhibited a concern for genuine policy change, notably a re-empowerment of the state in a 'globalised' market environment which has found only inadequate ways, if any, of dealing with the social and institutional dislocations it generates. With financial instability, old reservations resurfaced about both the absence of effective regulation of capital and the absence of mechanisms for correcting market failures. At a policy level, the 'dangers' of openness to globalised finance and the observation of global contagion revitalised neoKeynesian ideas about the role of the domestic economy in producing growth. Long-term growth projects based entirely on the vitalisation of the external sector, particularly in places like Argentina where the external sector still accounts for less than 10 per cent of GDP, were gradually (or not so gradually) losing currency among policy elites. Political climates at the end of the $1990 \mathrm{~s}$ were dominated by heightened awareness of the social responsibilities of governments, propelled by rising levels of popular mobilisation (in countries like Chile), increasingly salient social inequities (such as in Brazil) and persistently high levels of unemployment (most obviously in Argentina).

Whether these processes of re-evaluation will yield significant results remains to be seen. The observation that the financial crises propelled a scrutiny of neoliberal models does not mean that neoliberalism will be discarded as the dominant policy paradigm. Clearly, the hands of policy elites in the majority of South American countries remain tied by IMF agreements and the need to appease sources of investment and external finance. Concrete alternative policy agendas have yet to be articulated convincingly by domestic policy elites. It is, however, significant that even among prominent international political economists the espousal of unorthodox strategies by prominent international economists is much less uncommon than in the pre-Thai devaluation days: calls for capital controls being the most obvious example. 
The implications for regionalism, in this light, are two-fold. The first is that these changes in the constituent bases of regionalist projects (policy ideas and state interests) are likely, in ways which vary across regions and projects, to alter the nature of regionalism and the uses to which it is put. While financial crisis might not have weakened support for free(r) trade, it prompted a questioning of the 'one-size-fits-all' policy formula and consequently may strengthen articulations of regional 'identity' informed by political and socioeconomic realities, rather than by a globalised set of values and policy prescription s captured under the banner of 'Anglo-American neoliberalism'. This reconstitution may well take a shape which introduces elements of a more explicitly 'defensive' strategy in response to the pressures of multilateralism and globalism. While this is highly unlikely to translate directly into open protectionism, key departures from the principles of unfettered competition or complete deregulation, for example, seem to be strong possibilities. In short, the compulsion to conform with the minutiae of the 'globalised' neoliberal policy package appears increasingly diluted by a concern to find policy strategies appropriate to specific historical-institutional and economic settings and to implement policies to offset the raft of economic and political dislocations occasioned by global liberalisation.

The second is that the only viable means by which genuine policy change might be achieved is through collective action at the regional level. In the same ways that one of the primary functions of regionalism in the heyday of neoliberalis $m$ was to 'lock in' policy reform, future directions of policy change are likely of necessity to rely on the same mechanisms of regional collective action to increase the costs of deviation and also to construct political legitimation for a particular policy agenda. Moreover, the particular configuration of economic, institutional and political capacity resulting from the most recent period of capitalist instability necessitates collective action as the only means by which a range of public goods might be provided by governments. These arguments are elaborated in the next section.

\section{Regional collective action: coalescence or fragmentation?}

The suggestion, therefore, is that given the 'backlash' against unfettered globalisation, some 'regionalisation' of policy ideas seems likely as policy solutions sensitive to specifically local difficulties are sought, putting paid (yet again) to the notion of 'convergence' on a single, globalised set of values and policy principles. Meaningful policy change, however, is not easy and, moreover, does not come cheap. The capitalist world economy remains dominated by integrated trade and capital flows, unregulated financial markets and technological dynamism. Moreover, development strategies remain dependent on external capital resources, particularly in the aftermath of currency collapse. Political impetus for policy change in response to what we might call the 'globalisation of inequity' has a high price tag, especially in the absence of strong capital inflows or the presence of strong capital outflows. As a result, incentives for collective action are heightened as countries seek to maximise the international credibility of whichever policy responses are politically expedient in a given situation. 
It is here that our arguments about regionalism come into play. Given the difficulties associated with international cooperation in broader terms ${ }^{26}$ and in light of the relatively insignificant role that Latin American countries (and developing countries generally) play in international cooperation for the provision of public goods, regional collaboration may well retain its utility as a credibility-maximising and legitimacy-generating mechanism by which countries can pursue sets of similar goals in a globalising, currently volatile, international economy. As policy elites start to rethink their role in providing those collective goods associated with mitigating the worst impacts of socioeconomic dislocation-and indeed what those collective goods might be-the regional dimensions of that provision become decisive. And if states in Latin America (and other developing countries) are more concerned, for a variety of reasons, with the elimination or management of 'public bads', rather than the provision of collective goods ${ }^{27}$ then the regional dimension is all the more salient given the limitations on the political, institutional and economic capacities of these states to engage in this type of public policy. Finally, collective action is necessitated by the prior existence of a regional bloc and the need to maintain a balance of competitiveness. When this balance is disturbed by financial crisis or unilateral policy innovation, we can hypothesise that the maintenance of a regional project depends on collective action between states.

If, for example, South American countries are concerned to construct a model which is more socially responsive and politically sensitive, the options for funding such a shift in public policy are largely limited to increasing or restructuring taxation. Tax structures have important implications for balances of external competitiveness. Changes in the domestic distribution of tax burdens, especially in the presence of such structural imbalances as those which exist in the aftermath of precipitous devaluation, induce changes in the relative competitiveness of domestic industrial and external sectors. In the presence of a regional bloc, not only are perceptions of such competitive (dis)advantages heightened, especially in countries which are very significantly dependent on regional markets, but also pressures for reciprocal coordination between member countries are likely to emerge. For this reason policy initiatives which affect external competitiveness generally will flounder in the absence of collaboration. Both economic and political objectives may be seen to demand collective regional action in key areas of policy change. Increasingly loud calls from Argentina particularly for policy harmonisation in a range of areas respond directly to these considerations. Similar arguments apply to the introduction of social charters, or to labour flexibilisation initiatives.

Another illustration of this point may be found in the debates on regional currencies propelled by experiences of financial volatility at the end of the 1990s and the annihilation during this time of most forms of semi-fixed exchange rate regimes. The notion of some sort of triadic currency order-centred on regions currently structured around the dollar, euro and yen-has been floated frequently in discussions of the creation of a new 'global financial architecture'. ${ }^{28}$ Developments in South America in the aftermath of the Brazilian devaluation reflected these debates. Although generally a lone voice, Argentina's spirited defence of its currency, which is fully convertible to the dollar in a currency board 
arrangement established in 1991, was based on calls from government and some business elites for both the creation of a common Mercosur currency and/or the dollarisation of the Latin American region as a whole. ${ }^{29}$

However, the possibilitie s for European-style monetary union in South America would appear still to be limited. Although the notion of a 'little Maastricht' for the Mercosur gained considerable ground over the course of 1999 and the first part of 2000 , the Brazilians for the foreseeable future are likely to be unwilling to abandon the benefits of a floating exchange rate. ${ }^{30}$ Dollarisation, given the concessions it implies to the United States (and indeed its inauspicious start in countries like Ecuador), can be largely ruled out of future scenarios. Moreover, although Argentine preferences might find some resonance with Mexican business, for example, ${ }^{31}$ the likelihood that such a project would find even swampy ground in South America is diminished by precisely those factors which complicate the generation of collective responses to financial crisis. Despite the arguments for regional collective action outlined above, present evidence indicates that this can be only a long-term scenario, for two reasons. The first is that at present the Mercosur is not equipped to 'carry' the sort of integration that significant policy innovation might require. Its minimal level of institutionalisation and its slow progress on key (and basic) economic issuessuch as trade in services, government procurement, intellectual property, competition policy, harmonisation of customs procedures and exchange rate coordination-prompt scepticism about its capacity as a modus operandi for collective action.

The second and related issue is that the divergence between member countries for much of the late 1990s was far more pronounced than convergence. Key differences in economic structures and policy orientations (notwithstanding a general commitment to an economic development model which privileges open markets) generated significant tensions between Argentina and Brazil especially, not only on immediate policy issues but also on visions of the future of the regional project. These tensions were exacerbated by the Brazilian devaluation of early 1999 and led to a marked atomisation of policy responses, rather than increased coordination and cooperation. Superficial short-run collective responses-seen in the frenzy of summit meetings with the IMF, rhetorical commitments to 'support' from the US government, bail-out packages and 24-hour hotlines between Mercosur presidents - only thinly disguised increased regional atomisation as governments formulated responses most suited to particular national situations. The tension between Argentina and Brazil and the exigencies of responding to domestic instability pushed the regional agenda on to the back burner. While the Argentine government was calling for dollarisation and macroeconomic policy harmonisation, Brazilian elites were concerned with more specifically national priorities of dealing with the impact on prices and interest rates, and, no less important, in trying to salvage the fortunes of the beleaguered president Cardoso, rescue the reform agenda and bring the belligerence of the provincial governments under some semblance of centralised control.

Furthermore, as The Economist recently put it, 'weak presidents make weak diplomacy'. ${ }^{32}$ Given, as we have seen, that the Mercosur has to date been propelled by presidential summitry, it should come as no surprise that the 
fragility of the positions of both Cardoso and Menem in 1999 would have at least a 'stalling' effect on the regional agenda. As it turned out, the effect was to heighten hostility and generate the most profound crisis yet in the Mercosur. Brazil announced in February 2000, after plentiful rumours to the effect, that it was taking Argentina to the WTO to resolve a dispute over textiles exports. ${ }^{33}$ Former Argentine Economy Minister Cavallo called in August 1999 for a 'suspension' of the Mercosur while countries engaged in nationally-defined damage limitation exercises, ${ }^{34}$ and it was subsequently reported in early 2000 that the option of abandoning the Mercosur had been tabled before the Brazilian government. ${ }^{35}$ Despite the limited house-room that such proposals were afforded and the expressions of steadfast commitment from all governments and the subsequent flurry of new (and on the whole insubstantial) 'pacts', the significance of the questioning of the continued existence of the Mercosur should not be underestimated.

The short-term pattern thus indicates a fragmentation of the existing consensus, greater dissociation between Mercosur countries and the pursuit of increasingly individualistic policy agendas, rather than an enhancement of collective priorities. Optimistic accounts of the 'strengthening' of regionalism thus overlook important short-term dynamics of regional collective action, complicated by ongoing political wranglings within member countries, particularly between government and industry in Argentina. While we can accept that regionalism is a political project responsive to the manifold effects of global structural change-whether these are seen to be social degeneration, societal disarticulation, the profusion of new and traditional inequities, the disempowerment of developing countries, and so on-the inclusion of financial crisis in the picture alters the ways in which we understand collective action through regional cooperation. The limitations of the regional project itself indicate that the transformation of South American regionalis m into a genuine theatre for collective action and policy innovation is likely to occur only in the much longer term.

However, and crucially, these subregional dynamics cannot be treated in isolation from the process of hemispheric integration under negotiation since the 1994 Summit of the Americas in Miami. The notion of a Free Trade Area of the Americas (FTAA) has to date been secondary in importance (and vitality) to the development of subregional units and the vigorous pursuit of a patchwork of bilateral deals. It seems clear that the future of the FTAA will be determined by the interaction of the northern and southern hegemons. Given the divisive Congressional politics in the United States which have denied fast-track negotiating authority to the executive branch, Brazil retains its status as 'veto player' in the hemispheric negotiations. From the start, Brazil's interest in the Mercosur stemmed in large part from traditional tensions with the USA and from the potentially 'threatening' creation of the NAFTA. The resulting focus of Brazilian attention on consolidating its role as subregional hegemon led to the proposition in 1994 of the idea of a South American Free Trade Area (SAFTA) as a collective negotiating platform in the FTAA negotiations, and as an alternative to the USA's preferred country-by-country negotiating strategy. This has shifted of late to an emphasis on the expansion of the Mercosur to other South American countries but not, crucially, to the further institutionalisation of the regional 
arrangement nor to significant macroeconomic policy harmonisation between member countries. Brazilian opposition to these sorts of developments remains pronounced, but its commitment to opposing US negotiating strategies underlines its preferences for the expansion and reinforcement of the South American bloc. Current emphasis in the Mercosur on negotiations with the EU further dilutes the hemispheric agenda. On specific policy matters, the USA is seen to be promoting provisions which go beyond those agreed during the Uruguay Round, while Brazil's preference in the short term is to consolidate the measures agreed in the WTO. ${ }^{36}$ Similarly, Brazil and most other South American countries are concerned principally with trade issues, while the USA's objectives are more focused on 'newer' issues, such as services, intellectual property rights, competition policy, government procurement and environmental and labour standards.

Put this picture together with the fall-out from the Brazilian devaluation, as well as the 'backlash' resulting from the failure of the IMF and the US government to handle effectively the impending crisis over the second half of 1998 , and the prospects for the successful negotiation of a meaningful FTAA by 2005 appear complicated, to say the least. The rethinking of neoliberalis $m$ is likely to entrench longstanding differences between Brazil and the United States in approaches to economic management. As we have seen, the climate at the end of the 1990s favoured an expansion of governments' regulatory and managerial roles and capacities, tendencies already well-established in Brazilian preferences for strategic trade policies, active industrial policy and state-led development. Experiences of financial volatility are likely not only to have strengthened the southern countries' existing desire to negotiate as a coherent bloc, rather than as spokes around a hub, thereby generating enhanced potential for collective action, but also to accentuate the divergences between the north and south of the Americas.

Perhaps paradoxically, therefore, it is possible that the hostilities between Mercosur countries which complicate the generation of regional collective action will be diluted in the longer run by the greater opposition s between the north and south of the hemisphere, especially in the area of policy responses to globalisation and in the area of hemispheric integration. The nascent lineaments of a genuine regional identity that goes beyond the loose economic bloc, at present absent from the Mercosur, emerge most strongly in the context of the relationship with the United States and NAFTA. Brazil's unbending preference for subregional integration as opposed to a US-led hemispheric initiative has led to a situation in which each new move by the USA has pushed Brazil closer to its subregional commitments. ${ }^{37}$ When combined with the increased importance of regional collective action, for reasons of internal and external competitiveness and the requirements of policy change, the long-term scenario would appear to be one in which the regionalisation of a distinct form of South American capitalist organisation is a strong tendency. While collaboration within these 'smaller' regional constructions is far from uncomplicated by problems associated with collective action, as well as the limitations on the capacities of the Mercosur at the present time, it appears that these are the lines along which South American and hemispheric regionalism will be 'rethought'. 


\section{Global and regionalist governance}

So, in conclusion, what does all this tell us about the future of regionalism in a 'post-Washington Consensus' era? The complexity of the relationship between globalism, regionalism and the myriad of other levels of political and economic activity is not captured in now sterile assessments of whether open regionalism can in fact be open and whether regional blocs work to the detriment of multilateralism. ${ }^{38}$ Regionalism itself constitutes an element of an increasingly complex system of governance operating at a variety of levels in which questions about public goods, welfare, economic organisation and political participation are addressed. The re-accommodation of globalis $m$ and regionalism, as the principal structural consequence of the financial crises, therefore has its roots in key governance issues.

What is curious and telling, in this vein, is that these two levels of governance continue to be treated more or less in isolation from each other. In a recent volume on 'the political economy of world economic governance', for example, the regional dimensions of the future of governance were neglected almost entirely, mentioned only twice (on separate pages) in connection with the regional currencies debate. ${ }^{39}$ While most analyses of regionalism offer insights into its relationship with multilateralism or globalisation, very little of the global governance debate focuses on regionalism itself, beyond some appreciation of a 'regional' (for which read 'triadic') approach to the restructuring of the global financial architecture. Furthermore, the treatment of regionalism remains excessively 'aggregated'. Discussions of the relationship between globalism and regionalism suffer not only from their static qualities, but also from a propensity to treat 'regionalism' as a homogeneous phenomenon. Payne's illustration of the diversity of forms of regionalist governancemultilevel governance in the EU, 'hub-and-spoke governance' in North America and what he calls 'pre-governance' in Asia (which might, incidentally, apply usefully also to South America $)^{40}$ - highlights that simplistic conceptions of a single relationship between something called 'regionalism' and something called 'globalism' are analytically and empirically problematic.

These inadequacies in contemporary understandings of 'regional governance' are reflected in debates on the future structures and governance of the global political economy. Most obviously, the notion that the restructuring of the financial architecture will be undertaken with a strongly 'regional' bent is flawed, or at best unreflective of the regional and domestic dynamics which would inform such a project. Not only does it underestimate the variety of social forces that needs to be incorporated into analyses of governance and the plethora of 'levels' at which sites of authority are located, it also misconceives the dynamics of regionalism in the 'aftermath' (or else temporary lull) of financial crisis in various parts of the world. The resulting assumptions guiding debates at the start of the new decade are thus dubious.

First, the projected division of the world into a triadic structure paints lines of connection between 'regions', countries and actors which appear erroneous. While they make some (limited) sense in terms of currency arrangements, they have little coherence when we consider other dimensions of convergence 
and conflict in the global political economy. In the area of policy ideas, for example, there is some significant convergence between East Asia and Europe and, crucially now, South America. The closer identification by South American government elites with the key policy debates associated with European 'centre-left' governments is exacerbated by the continuing insistence by the US government and associated international institutions on a deepening of neoliberal stringency. This is reflected, furthermore, in a smattering of calls in South American countries for the establishment of closer relations with Europe in preference to the United States ${ }^{41}$ as well as in the current political negotiations for EU-Mercosur trade agreements. The arrows of 'cooperation' thus point in directions not immediately consistent with a global triad of 'regional' constructions. While Europe's proposals for the construction of 'monetary zones' as a means of containing financial volatility are broadly supported in East Asia and received sympathetically in South America, it is far from clear that these might correspond to a structure of 'regionalist governance' in the wider sense capable of transcending increasing tensions in the 'regions' of the Americas and the Asia Pacific.

Second, the idea of a triadic structure takes no account of the emerging importance of subregional identification as the apparently strongest basis for the future trajectory of regionalism. We have seen that the dynamics of South American regionalism do not augur well for anything more than a loose network of 'hemispheric' relationships, if in fact an FTAA does come to any sort of fruition. Similar trends can be observed in the fragmentation of APEC. Perspectives on regionalist governance from a 'globalist' perspective do not sit well with considerations of specific domestic and regional dynamics which inform emerging structures of governance.

In this vein, and third, the 'globalisation backlash' has sharpened tensions between the more and less developed countries - seen clearly in the Seattle meetings of the World Trade Organization in late 1999-which are neglected by these globalist imaginings of new regionalist governance. Given that the most prominent trend of recent years has been the globalisation of inequity, the financial crises generated resurgent perceptions of structures of 'disadvantage' in the global political economy. Moral hazard, for example, shifted the liabilities of financial markets and the impact of their behaviour to those 'emerging' markets targeted by speculative capital. The impact of massive capital flight exacerbated pronounced social dislocations in developing countries occasioned by global neoliberalism. The reactions against inequity and disadvantage, therefore, are significantly bound up with power relations in the global political economy and would be most likely to militate against cooperation at the levels suggested by ideas of triadic governance, especially in the Americas. As we have seen at various points in the discussion, emerging patterns of 'spoke-spoke' relationships are potentially of equal utility to (if not greater than) 'hub-spoke' interactions. If regionalism is strengthened as a means by which global polarisation might best be addressed, the notion of triadic governance structures is anachronistic to the sharpened appreciations, including in South America, of the prejudicial dimensions of the globalist project. 


\section{Notes}

1. The working understanding of 'globalisation' employed here refers to the progressive integration, liberalisation, deregulation and privatisation of the international economy and its constituent parts. Thus it refers to the dominant policy and economic understanding s of the term, without ignoring the complexity of its contemporary usage.

2. Rosenau's recent definition of 'governance' seems to have become the standard understanding of the term. He refers to 'spheres of authority at all levels of human activity ... that amount to systems of rule in which goals are pursued through the exercise of control'. James N. Rosenau, Along the Domestic-Foreign Frontier: Exploring Governance in a Turbulent World (Cambridge University Press, 1997), p. 145.

3. Robert W. Cox, 'Structural issues of global governance: implications for Europe', in: Stephen Gill (Ed.), Gramsci, Historical Materialism and International Relations (Cambridge University Press, 1993), pp. 259-89.

4. Joseph Stiglitz, 'More instruments and broader goals: moving toward the post-Washington Consensus', 1998 WIDER Annual Lecture, Helsinki, 7 January 1998: from http://www.worldbank.org/html/extdr/ extme/js-010798/wider.htm.

5. Eric Helleiner, 'Post-globalization: is the financial liberalization trend likely to be reversed?', in: Robert Boyer \& Daniel Drache (Eds), States Against Markets: The Limits of Globalization (Routledge, 1996), pp. 193-210. Susan Strange also predicted as early as 1986 a 'political backlash' against what she termed 'casino capitalism'. Casino Capitalism (Blackwell, 1986), pp. 192-3.

6. Daniel Bach \& Helge Hveem, 'Regionalism, regionalization and globalization', paper presented to the Third Pan-European International Relations Conference and Joint Meeting with the International Studies Association, Vienna, 16-19 September 1998.

7. For comparative perspectives on the impact of crisis on APEC and other Asian regional groupings, see Mark Beeson, 'Reshaping Regional Institutions: APEC and the IMF in East Asia', The Pacific Review, Vol. 12, No. 1 (1999), pp. 1-24; Zakaria Haji Ahmed \& Baladas Ghoshal, 'ASEAN's Political Evolution and the Indonesian Crisis', International Affairs, Vol. 75, No. 4 (1999), pp. 759-78; and Mark T. Berger, 'APEC and its Enemies: The Failure of the New Regionalism in the Asia Pacific', Third World Quarterly, Vol. 20, No. 5 (1999), pp. 1013-30.

8. For examples of this literature, see Kenichi Ohmae, The Borderless World: Power and Strategy in the Interlinked Economy (Harper Collins, 1996); and, in a less 'purist' vein, Susan Strange, The Retreat of the State: The Diffusion of Power in the World Economy (Cambridge University Press, 1996).

9. As examples of this huge literature, see Peter Evans, 'The Eclipse of the State? Reflections on Stateness in an Era of Globalization', World Politics, Vol. 50 (1997), pp. 62-87; John Zysman, 'The Myth of a "Global" Economy: Enduring National Foundations and Emerging Regional Realities', New Political Economy, Vol. 1, No. 2 (1996), pp. 157-84; Jan Aart Scholte, 'Global Capitalism and the State', International Affairs, Vol. 73, No. 3 (1997), pp. 427-52; Linda Weiss, The Myth of the Powerless State: Governing the Economy in a Global Era (Polity Press, 1998); and Boyer \& Drache, States Against Markets.

10. Anthony Payne, 'Globalisation and modes of regionalist governance', in: Jon Pierre (Ed.), Debating Governance: Authority, Steering and Democracy (Oxford University Press, 2000), p. 202.

11. See, for example, Gary Marks, Liesbet Hooghe \& Kermit Blank, 'European Integration from the 1980s: State-Centric v. Multilevel Governance', Journal of Common Market Studies, Vol. 34, No. 3 (1996), pp. 341-78.

12. Paul Hirst \& Grahame Thompson, Globalization in Question: The International Economy and the Possibilities of Governance (Polity Press, 1996), pp. 149-51.

13. Anthony Payne \& Andrew Gamble, 'Introduction: the political economy of regionalism and world order', in: Andrew Gamble \& Anthony Payne (Eds), Regionalism and World Order (Macmillan, 1996), p. 2.

14. Gordon Mace \& Louis Bélanger, 'Hemispheric regionalism in perspective', in: Gordon Mace, Louis Bélanger et al., The Americas in Transition: The Contours of Regionalism (Lynne Rienner, 1999), p. 1.

15. The Mercado Común del Sur (Southern Common Market), established in 1991 by Argentina, Brazil, Paraguay and Uruguay. Chile and Bolivia are associate members.

16. Mónica Hirst, 'La Dimensión Política del Mercosur: Actores, Politización e Ideología', Serie de Documentos e Informes de Investigación No. 198, FLACSO, Buenos Aires, 1995, pp. 4-6.

17. See, for example, Andrew Moravcsik, 'Preferences and Power in the European Community: A Liberal Intergovernmentalis t Approach', Journal of Common Market Studies, Vol. 31, No. 4 (1993), pp. 473-523; and Stanley Hoffman, 'Reflections on the Nation-State in Western Europe Today', Journal of Common Market Studies, Vol. 21 (1982), pp. 21-37. 
18. Richard Higgott \& Nicola Phillips, 'Challenging Triumphalism and Convergence: The Limits of Global Liberalization in Asia and Latin America', Review of International Studies, Vol. 26, No. 3 (2000), pp. 359-79.

19. 'Paying lip service to reform of a disruptive world system', International Herald Tribune, 5 February 1999; and 'Third world woes dominate first world summit', The Financial Times, 27 April 1999.

20. Dani Rodrik, Has Globalization Gone Too Far? (Institute for International Economics, 1997); and Paul Krugman, The Return of Depression Economics (Allen Lane, The Penguin Press, 1999).

21. Sebastian Edwards, 'Latin America's Underperformance', Foreign Affairs, Vol. 76, No. 2 (1997), p. 102.

22. Mario Rodarte, 'El FMI en la crisis', El Economista (Mexico), 7 October 1998. Also 'Hay que evitar el efecto contagio en la región', El Cronista (Argentina), 25 August 1998.

23. Karl Polanyi, The Great Transformation: The Political and Economic Origins of Our Time (Beacon Press, 1944); and John Gerard Ruggie, 'At Home Abroad, Abroad At Home: International Liberalisation and Domestic Stability in the New World Economy', Millennium: Journal of International Studies, Vol. 24, No. 3 (1995), pp. 507-26.

24. See Geoffrey Garrett, 'Global Markets and National Politics: Collision Course or Virtuous Circle?', International Organization, Vol. 52, No. 4 (1998), pp. 787-824.

25. Headlines in El Nacional (Venezuela), 8 October 1998 and Excelsior (Mexico), 7 October 1998.

26. See Helen Milner, Interests, Institutions and Information: Domestic Politics and International Relations (Princeton University Press, 1997).

27. See Nicola Phillips \& Richard Higgott, Global Governance and the Public Domain: Collective Goods in a Post-Washington Consensus Era, ESRC Centre for the Study of Globalisation and Regionalisation, University of Warwick, Working Paper 47/99, November 1999.

28. See Barry Eichengreen, Toward a New International Financial Architecture: A Practical Post-Asia Agenda (Institute for International Economics, 1999); United Nations, Task Force of the Executive Committee on Economic and Social Affairs, 'Towards a new international financial architecture', 22 January 1999: from http://www.eclac.cl/English/Coverage/architecture.htm; and José Antonio Ocampo, 'Reforming the international financial architecture: consensus and divergence', CEPAL, Serie Temas de Coyuntura, April 1999.

29. See, for example, 'Menem forces dollar plan to top of political agenda in Argentina', The Financial Times, 27 January 1999; 'No More Peso?', The Economist, 23 January 1999; 'A Yankee currency for Argentina?', International Herald Tribune, 4 February 1999; and 'El largo camino hacia la desaparición del peso', El Economista (Argentina), 14 May 1999.

30. For a discussion, see Victor Bulmer-Thomas, 'The Brazilian Devaluation: National Responses and International Consequences', International Affairs, Vol. 74, No. 4 (1999), pp. 729-41.

31. Zanny Minton Beddoes, 'From EMU to AMU? The Case for Regional Currencies', Foreign Affairs, Vol. 78, No. 6 (1999), pp. 8-13.

32. 'Sour Mercosur', The Economist, 14 August 1999.

33. The Financial Times, 16 February 2000.

34. 'Mercosul: Cavallo sugere interrupção', news bulletin from Agência Estado (Brazil), 6 August 1999: from http://www.agestado.com.br.

35. Mercopress News Agency, 8 February 2000 (http://www.mercopress.com).

36. For broader discussions of Brazilian positions on the FTAA, see Paulo S. Wrobel, 'A Free Trade Area of the Americas in 2005?', International Affairs, Vol. 74, No. 3 (1998), pp. 547-61; Jean Grugel \& Marcelo de Almeida Medeiros, 'Brazil and Mercosur', in: Jean Grugel \& Wil Hout (Eds), Regionalism across the North-South Divide: State Strategies and Globalization (Routledge, 1999), pp. 46-61; and Roberto Bouzas, 'Mercosur's external trade negotiations: dealing with a congested agenda', in: Riordan Roett (Ed.), Mercosur: Regional Integration, World Markets (Lynne Rienner, 1999), pp. 81-93.

37. Maria Regina Soares de Lima, 'Brazil's alternative vision', in: Mace, Bélanger et al., The Americas in Transition, p. 136.

38. Such as Edward D. Mansfield \& Helen V. Milner, 'The New Wave of Regionalism', International Organization, Vol. 53, No. 3 (1999), pp. 589-627.

39. Jonathan Michie \& John Grieve Smith (Eds), Global Instability: The Political Economy of World Economic Governance (Routledge, 1999).

40. Payne, 'Globalisation and Modes of Regionalist Governance', pp. 211-15.

41. For example, 'La Alianza apunta hacia Chile, Europa, Asia y el Mercosur', La Nación (Argentina), 16 May 1999. 